\title{
Determination of Antifungal and Antioxidant Activitiy of Salvia tomentosa
}

\author{
Yusuf BAYAN ${ }^{1}$, Nusret GENÇ²
}

\begin{abstract}
In this study, was determined antifungal and antioxidant activity of Salvia tomentosa. The essential oil of Salvia tomentosa was determined of the percentages of mycelium inhibition agains plant pathogenic fungi Rhizoctonia solani and Alternaria solani $40.63 \%$ and $60.13 \%$ respectively. To determine the antioxidant capacity, Free radical reduction (scavenging), iron reduction power (FRAP), copper reduction power (CUPRAC) and free radical cations reduction (TEAC), total phenolic (TP) and total flavonoids (TF) tests were performed. The results of the tests, scavenging activity DPPH $1 C_{50} 15.08 \pm 1.28\left(\mu \mathrm{g} \mathrm{mL}^{-1}\right)$, FRAP $1.81 \pm 0.27 \mathrm{mmol} \mathrm{TE} \mathrm{g}^{-1}$ extract, CUPRAC $5.57 \pm 0.20 \mathrm{mmol} \mathrm{TE} \mathrm{g}^{-1}$ extract and TEAC ise $3.30 \pm 0.33 \quad \mathrm{CC}_{50}\left(\mu \mathrm{g} \mathrm{mL}^{-1}\right)$ was determined. Total phenolic and total flavonoid was determined to be extracted content $131.34 \pm 8.39 \mathrm{mg} \mathrm{GAE} \mathrm{g}^{-1}$ of extract and 35.05 $\pm 2.82 \mathrm{QA} \mathrm{g}^{-1}$ respectively.
\end{abstract}

Keyword; Antifungal, antioxidant, salvia tomentosa, total phenolic, essential oil

\section{Salvia tomentosa'nin Antifungal ve Antioksidant Aktivitesinin Belirlenmesi}

ÖZET: Bu çalışma, Salvia tomentosa'nın antifungal ve antioksidant aktivitesi belirlenmesi amacıyla yürütülmüştür. Salvia tomentosa'nın uçucu yağı bitki patojeni fungus olan, Rhizoctonia solani ve Alternaria solani 'nin miselyum gelişim sırasıyla \% 40.63 ve \% 60.13 engellemiştir. Antioksidan kapasitesini belirlemek için, Serbest Radikal Giderme (DPPH), Demir İndirgeme Gücü (FRAP), Bakır İndirgeme Gücü (CUPRAC) ve Serbest Katyon Radikali Giderme (TEAC) antioksidan aktivite testleri ile Toplam Fenolik (TP) ve Toplam Flavonoid (TF) miktarı analizleri yapılmıştır. Yapılan antioksidan testleri sonucunda, DPPH $1 C_{50} 15.08 \pm 1.28\left(\mu \mathrm{g} \mathrm{mL}^{-1}\right)$, FRAP $1.81 \pm 0.27 \mathrm{mmol} \mathrm{TE}$ $\mathrm{g}^{-1}$ eksrakt, CUPRAC $5.57 \pm 0,20 \mathrm{mmol} \mathrm{TE} \mathrm{g}^{-1}$ ekstrakt ve TEAC ise $3.30 \pm 0.33 \mathrm{lC}_{50}\left(\mu \mathrm{g} \mathrm{mL} \mathrm{L}^{-1}\right)$ olarak belirlenmiş̧ir. Toplam fenolik ve toplam flavanoid içeriği sırasıyla $131.34 \pm 8.39 \mathrm{mg} \mathrm{GAE} \mathrm{g}^{-1}$ ekstrakt ve $35.05 \pm 2.82 \mathrm{mg} \mathrm{QE} \mathrm{g}^{-1}$ ekstrakt olarak tespit edilmiştir.

Anahtar Kelimeler; Antifungal, antioksidant, salvia tomentosa, toplam fenolik, uçucu yağ

Yusuf BAYAN (0000-0001-8393-7218), Ahi Evran Üniversitesi, Ziraat Fakültesi, Bitki Koruma, Kırşehir, Türkiye

Nusret GENÇ (0000-0003-3685-1344), Gaziosmanpaşa Üniversitesi, Fen-Edebiyat Fakültesi, Kimya, Tokat, Türkiye Sorumlu yazar/Corresponding Author: Yusuf BAYAN, yusufbayan@gmail.com 


\section{INTRODUCTION}

Numerous plants have been used for various purposes, like perfumery, drugs and food. Salvia species, a member of Lamiaceae family, one of the most significant species of this group. Salvia species, usually used as sage, have been used since old times for more primarily to treat colds, bronchitis, tuberculosis, cancer, diabetes, bleeding and menstruous diseases. In addition, this species are used as traditional medicines all around the world, in possession of antitumor, antidiabetic, antioxidant, and antibacterial features. (Heath, 1981;Topcu, 2006; Celep et al., 2009). Salvia species incorporate differend secondary metabolites like diterpenoids, essential oils, sterols, flavonoids, sesquiterpenoids, sesterpenoids, and flavonoids (Ulubelen et al., 1997; Esquivel et al., 2000). The some of phenolic compounds of plants member of this genus have shown perfect antimicrobial activity. Besides, Salvia species have scavenging activity of active oxygen, as in superoxide anion radicals, singlet oxygen and hydroxyl radicals (Masaki, et al., 1995; Tepe, et al., 2005)

Salvia tomentosa is a species common in Turkey. This plant is a perennial flowering plants in AprilAugust. Body upright and $1 \mathrm{~m}$ long, four-cornered, and often It is branched. Flower stalks $5-10 \mathrm{~mm}$, calyx is 12 $16 \mathrm{~mm}$ (Davis, 1982). Considering have a significant medical potential of plants in Turkey, information of the this issue and works on plants are limited (Tepe, et al., 2005).

In this study, was aimed to determine of the antioxidant and antifungal activity of the constituents of S. tomentosa grown naturally in Kahramanmaras, Turkey.

\section{MATERIALS AND METHODS}

\section{Plant Material}

The flowered branches of $S$. tomentosa were collected from Turkoglu /Kahramanmaras, Turkey, flowering stage in Jun 2016. Plant materials were dried under shadow and room temperature. The plant specimens were identified by Dr. Melih Yılar.

\section{Extraction of Essential Oils}

The wet plant material was exposed to hydro distillation for $2 \mathrm{~h}$ using a Neos essential oils system.
The essential oil from dried parts samples were preserved in a sealed vial at $4{ }^{\circ} \mathrm{C}$ until analysis.

\section{Total Phenolic Contents}

The total phenolic compound was determination by Folin-Ciocalteus reagent with small modification (Slinkard and Singleton, 1977). For this purpose, plant extract $0.1 \mathrm{ml}$ was mixed with distille water $4.6 \mathrm{ml}$. On $0.3 \mathrm{ml}$ of $\mathrm{Na} 2 \mathrm{CO} 3$ solution (2\%) and $0.1 \mathrm{ml}$ of FolinCiocalteus reagent was added to the mixed. It was incubated for 2 hours at room conditions. Absorbance was measured at $760 \mathrm{~nm}$. As result of gallic acid equivalents (GAE) $\mathrm{g}^{-1}$ of extract was calculated.

\section{Determinations of Total Flavonoid Assay}

The plant sample total flavonoid contents were determined by (Chang, at al., 2002). Plant extract 0.1 $\mathrm{ml}$ was mixed with methanol $4.8 \mathrm{ml} .0 .1 \mathrm{ml} \mathrm{Al}\left(\mathrm{NO}_{3}\right)$ (10\%) and $0.1 \mathrm{ml} \mathrm{NH}_{4} \mathrm{CH}_{3} \mathrm{COO}$ solution (1M) was added to the mixed. It was incubated for 45 munite at room conditions. After the absorbance were measured at $415 \mathrm{~nm}$. As result of quarcitin equivalents $(\mathrm{QE}) \mathrm{g}^{-1}$ of extract was calculated.

\section{DPPH· Free Radical-Scavenging Activity}

The free radical scavenging activity were determined by Liana-Pathirana made a few changes in the method (Liyana-Pathirana and Shahidi, 2005). Plant methanol ekstracts was differend amounts stock solutions by placing of test tube and volume was completed to $3 \mathrm{ml}$ with ethyl alcohol. Over them $1 \mathrm{ml}$ of DPPH solution $(0.26 \mathrm{mM})$ was added and stirred with the help of vortex. After standing for 30 minutes in a dark ambient, the absorbance was read at $517 \mathrm{~nm}$. The data obtained were expressed as $\mathrm{IC}_{50}$. The radical scavenging activity was calculated from the equations.

$$
\left.\mathrm{I}_{\mathrm{DPPH}=} \text { 100.[ } \mathrm{A}_{\text {control }}-\left(\mathrm{A}_{\text {sample }}-\mathrm{A}_{\text {blank }}\right)\right] / \mathrm{A}_{\text {control }}
$$

\section{Iron Ion Reducing Antioxidant Power (FRAP)}

The FRAP analysis method applied by Oyaiz (1986) was performed through amendments. 0.25 $\mathrm{ml}$ plant extract of $0.2 \mathrm{M}$ phosphate buffer ( $\mathrm{pH}$ 6.6) with $1.25 \mathrm{~mL}$ complete. On $1.25 \mathrm{ml}$ of potassium ferricyanide $\left[\mathrm{K}_{3} \mathrm{Fe}(\mathrm{CN})_{6}\right]$ solution $(1 \%)$ was added. The mixture was incubated at $50^{\circ} \mathrm{C}$ for 20 minutes. The mixture cooling to room temperature TCA (1.25 $\mathrm{mL}, 10 \%)$ and $\mathrm{FeCl} 3(0.25 \mathrm{~mL}, 0.1 \%)$ solution were added. After stirring vortex was measured absorbance 
at $70 \mathrm{~nm}$. The results obtained was Trolox equivalent (TE), calculated.

\section{Cupric Reducing Antioxidant Capacity (CUPRAC)}

The cunpric antioxsidant capacity was determined by Chang (2002), with slight modifications. Results were compared with used in standard antioxidants BHA and BHT absorbance.

\section{Fungal Cultures}

The plant pathogenic fungi used were obtained from the stock cultures of the Department of Plant Protection, Faculty of Agriculture, University of Ahi Evran, Turkey.

\section{In Vitro Antifungal Effect of the Essential Oils}

The antifungal activities of essential oil were determined by the agar well diffusion method (Tepe, et al., 2005). The PDA were autoclaved and cooled to $40^{\circ}$. Later were transferred to $60 \mathrm{~mm}$ petri dishes $\left(10 \mathrm{ml}\right.$ petri $\left.{ }^{-1}\right) .5 \mathrm{~mm}$ diameter wells were opened on the PDA inside the petri dishes. The plant essential oils were transferred 1,5 and $10 \mu$ petri $^{-1}$ inside the wells. Mycelium disks of $5 \mathrm{~mm}$ were later placed at equal distances to these wells. The fungi transferred petri dishes were incubated at $22 \pm 2^{\circ} \mathrm{C}$. According to mycelium inhibitions was calculated the formulated.

$$
\mathrm{I}=100 \times(\mathrm{DC}-\mathrm{DT}) / \mathrm{DC}
$$

I: Inhibition percentage compared to the control (mycelium development)

DC: Mycelium development in the control

DT: Mycelium development in essential oils applications

\section{RESULT AND DISCUSSION}

\section{In Vitro Antifungal Results}

Essential oils of the S.tomentosa, were found to be significantly effective mycelium grow on $R$. solani and A. solani. The antifungal activity properties of essential oil of the S. tomentosa in-vitro are shown in table 1.

Table 1. Antifungal activity values (Inhibition (\%) and Inhibition zone) for S. tomentosa Mill. essential oil.

\begin{tabular}{|c|c|c|c|c|}
\hline \multirow{3}{*}{$\begin{array}{l}\text { Doses } \\
\left(\mu l \text { petri }^{-1}\right)\end{array}$} & \multicolumn{4}{|c|}{ Plant Pathogens } \\
\hline & \multicolumn{2}{|l|}{${ }^{* *} \mathbf{R} . \mathbf{S}$} & \multicolumn{2}{|l|}{ A.s } \\
\hline & $\mathbf{I}^{(\%)}$ & $\mathbf{I z}^{(\mathrm{mm})}$ & $\mathbf{I}^{(\%)}$ & $\mathbf{I} \mathbf{z}^{(\mathrm{mm})}$ \\
\hline $\mathrm{NC}$ & $0.00^{c^{*}} \pm 0.0$ & 60 & $0.00^{\mathrm{d}} \pm 0.0$ & 60 \\
\hline 1 & $0.00^{c} \pm 0.0$ & 60 & $16.46^{\mathrm{c}} \pm 1.16$ & 50.12 \\
\hline 5 & $20.06^{\mathrm{b}} \pm 0.17$ & 47.96 & $29.50^{\mathrm{b}} \pm 1.21$ & 42.3 \\
\hline 10 & $40.63^{\mathrm{a}} \pm 2.71$ & 35.61 & $60.12^{\mathrm{a}} \pm 1.43$ & 23.92 \\
\hline
\end{tabular}

* According to DUNCAN, the averages with different letters in the same column are different at the significance level of $\mathrm{p}<0.05$ **A. solani (A.s), R. solani (R.s) Negative control (NC)

The essential oil had antifungal activity agains plant pathogenic fungi R.solani and A. solani $40.63 \%$ and $60.13 \%$ respectively. The essential oil a great had antifungal activity of agains $A$. solani and the least agains $R$. solani. Provious differet studies of the $S$. tomentosa, was reported antifungal activity. Yilar and kadioglu (2016) S. tomentosa essantial oil, methanol and aquatic extract, have reported antifungal activity of F. oxysporum f. sp.radicis lycopersici. Haznedaroglu et al (2001) essential oil of the $S$. tomentosa have reported antibactericidal effects. This study and similar previous studies showed that essential oil of the S. tomentosa are effective mycelium development on $R$. solani and $A$. solani. 


\section{Antioxidant Activity Results}

Table 2. Antioxidant activity of $S$. tomentosa of the methanol extract by TP, TF, DPPH, TEAC, Reducing power and CUPRAC ${ }^{\text {. }}$

\begin{tabular}{|c|c|c|c|c|c|c|}
\hline Sample & $\begin{array}{l}\text { TP } \\
\text { mg GAE g-1 } \\
\text { extract }\end{array}$ & $\begin{array}{l}\text { TF } \\
\text { mg QE } \text { g }^{-1} \\
\text { Extract }\end{array}$ & $\begin{array}{l}\text { DPPH } \\
\text { IC }_{50}\left(\mu \mathrm{g} \mathrm{mL} L^{-1}\right)\end{array}$ & 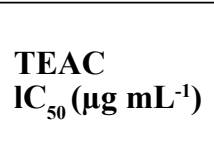 & $\begin{array}{l}\text { Reducing } \\
\text { power } \\
\text { mmol TE } g^{-1} \\
\text { extract }\end{array}$ & $\begin{array}{l}\text { CUPRAC } \\
\text { mmol TE } \mathrm{g}^{-1} \\
\text { extract }\end{array}$ \\
\hline $\begin{array}{l}\text { Methanol } \\
\text { extract }\end{array}$ & $131.34 \pm 8.39$ & $35.05 \pm 2.82$ & $15.08 \pm 1.28$ & $3.30 \pm 0.33$ & $1.81 \pm 0.27$ & $5.57 \pm 0.20$ \\
\hline $\mathrm{BHA}^{\mathrm{b}}$ & & & $4.52 \pm 0.67$ & $3.30 \pm 0.05$ & $6.60 \pm 0.16$ & $15.99 \pm 1.07$ \\
\hline $\mathrm{BHT}^{\mathrm{b}}$ & & & $8.45 \pm 0.67$ & $9.40 \pm 0.55$ & $2.74 \pm 0.35$ & $15.25 \pm 0.61$ \\
\hline Trolox $^{b}$ & & & $3.50 \pm 0.03$ & $4.80 \pm 0.06$ & & \\
\hline
\end{tabular}

a IC50 values represent the means the standard deviation of three parallel measurements $(\mathrm{p}<0.05)$.

${ }^{\mathrm{b}}$ Standart compounds

The total flavonoid and total phenolic, antioxidant activity of $S$. tomentosa methanol extract are shown in table 2. The results of total phenolics content of the sample analysed was $131.34 \pm 8.39$ gallic acid equivalents mg (GAE) $\mathrm{g}^{-1}$ of extract. Total phenolic content of $S$. tomentosa extracted with various solvents ranged widely, among 10 and $275 \mu \mathrm{g} \mathrm{GAE} \mathrm{mg}^{-1}$ (Tepe, et al., 2005; Erdogan-Orhan, et al., 2010). In our studies result, was $131.34 \mathrm{mg}$ (GAE) $\mathrm{g}^{-1}$, which is support to with our results.

The total flavonoid content of $S$. tomentosa methanolic extract was $35.05 \pm 2.82$ quarcitin equivalents $\mathrm{mg}(\mathrm{QE}) \mathrm{g}^{-1}$ of extract table 3. Previous studies, Dincer et al (2013) reported that the total flavonoid content of $S$. tomentosa $40.83 \mathrm{mg}$ of CE g ${ }^{-1} \mathrm{dw}$, which is support to with our results. Also total pheneolic and flavonoid content, results maybe effected of the geographical positions of the plants, ecological conditions, and climate (Papageorgiou, et al., 2008).

The plant seconder metabolites, sach as phenolics and flavonoids, have antioxidant activity because thire redox feature (Baba, et al., 2015). The methanol extract $\mathrm{IC}_{50}$ values of $S$. tomentosa $15.08 \mathrm{mg} / \mathrm{ml}$ DPPH table. Dincer, et al (2013) have reported that $\mathrm{IC}_{50}$ values of $S$. tomentosa methanol extract $2.29 \mathrm{mg} \mathrm{dw} \mathrm{mg}^{-1}$. ABTS scavining ativity of $S$. tomentosa methanol extract are presented table 3 . The ABTS activity of methanol extract were found to be beter than standart BHT and Trolox, but with same BHA. The table.. showed the reducin power of the methanol extract and standart, such as BHA and BHT. The excellent reducing power methanol crude extract $1.81 \pm 0.27 \mathrm{mmol} \mathrm{TE} \mathrm{g}^{-1}$ extract, compare with standart BHA and BHT. CUPRAC reducin power of methanol extract sample $5.57 \pm 0.20$ mmol TE $\mathrm{g}^{-1}$ extract was determined. The CUPRAC reducin power activity of methanol extract were found to be better than standart BHA and BHT table 2. S. tomentosa methanol extract was exhibited strong of the antioxidant actvity, fonolics compoud or flavonoids may be also play important roles in the activity.

\section{CONCLUSION}

In this study, was determined antifungal and antioxidant activities $S$. tomentosa The results of this work have shown essentail oil significant antifungal activity against $R$. solani and A. solani. As a result of, methanol extract from $S$. tomentosa was showed considerable antioxidant activity. Also, methanol extract was determined content total phenolic and flavonoid. These studies, can be used in management of plant pathogenic fungi diseases control.

\section{REFERENCES}

Chang C.-C,Yang MH, Wen HM. Chern JC 2002. Estimation of total flavonoid content in propolis by two complementary colorimetric methods; J. FoodDrug Analysis, 10: 178-182.

Erdogan-Orhan I, Baki E, Senol S, Yilmaz G 2010. Sage-called plant species sold in Turkey and their antioxidant activities. J Serb Chem Soc 75: 1491-1501.

Esquivel B, Sanchez AA, Aranda E. 2000.Natural Products of Agricultural Interest from Mexican Labiatae. In: Shahidi F. and Ho CH. eds. Phytochemicals and Phytopharmaceuticals. AOCS Press: 371-385.

Haznedaroğlu MZ, Karabay NU, Zeybek U 2001. Antibacterial activity of Salvia tomentosa essential oil. Fitoterapia. 72: 829-831. 
Liyana-Pathirana CM, F Shahidi 2005. Antioxidant activity of commercial soft and hard wheat (Triticum aestivum L.) as affected by gastric $\mathrm{pH}$ conditions. J. Agric. Food Chem., 53: 2433-2440.

Masaki H, Sakaki S, Atsumi T, Sakurai H 1995. Activeoxygen scavenging activity of plant extracts. Biological and Pharmacological Bulletin, 18(1): 162-166.

Oyarzu M, 1986. Studies on product of browning reaction prepared from glucose amine. Japan Journal of Nutrition, 44: 307-315.

Papageorgiou V, Gardeli C, Mallouchos A, Papaioannou M, Komaitis M 2008. Variation of the chemical profile and antioxidant behavior of Rosmarinus officinalis L. and Salvia fruticosa Miller grown in Greece. J Agr Food Chem 56: 72547264.

Re R, Pellegrini N, Protrggente A, Pannala A, Yang, M, Rice-Evans C 1999. Antioxidant activity applying an improved ABTS radical cation decolorization assay. Free Radical Biology and Madicine, 26: 1231-1237.

Singleton VL, Orthofer R, Lamuela-Raventos RM 1999. Analysis of total phenols and other oxidation substrates and antioxidants by means of Folinciocalteu reagent. Methods in Enzymology, 299: $152-178$
Tepe B, Daferera D, Sokmen A, Sokmen M, Polissiou M 2005. Antimicrobial and antioxidant activities of the essential oil and various extracts of Salvia tomentosa Miller (Lamiaceae). Food Chemistry 90: 333-340.

Tepe B, Daferera D, Sokmen A, Sokmen M, Polissiou Moschos 2005. Antimicrobial and antioxidant activities of the essential oil and various extracts of Salvia tomentosa Miller (Lamiaceae) Food Chemistry. $90: 333-340$.

Ulubelen A 2003. Cardioactive and antibacterial terpenoids from some Salvia species. Phytochemistry, 64: 395-399.

Ulubelen A, Topcu G, Bozok-Johansson C 1997. Norditerpenoids and diterpenoids from Salvia multicaulis with antituberculous activity. J Nat Prod 60: 1275-1280.

Y1lar, M, Kadıoglu I 2016. Antifungal Activities of some Salvia Species Extracts on Fusarium oxysporum f. sp. radicislycopersici (Forl) Mycelium Growth In-vitro. Egyptian Journal of Biological Pest Control, 26(1): 115-118 